\title{
Persepsi mahasiswa pendidikan matematika FKIP Universitas Mataram terhadap pembelajaran daring di era COVID-19
}

\author{
Nurdianti $^{1 *}$, Sudi Prayitno², Amrullah ${ }^{2}$, Nani Kurniati ${ }^{2}$ \\ ${ }_{1}^{1}$ Mahasiswa Pendidikan Matematika, FKIP, Universitas Mataram, Mataram \\ ${ }^{2}$ Pendidikan Matematika, FKIP, Universitas Mataram, Mataram \\ nurdiantidina67@gmail.com
}

Diterima:17-12-2021; Direvisi: 29-12-2021; Dipublikasi: 30-12-2021

\begin{abstract}
This study aims to determine the perception of mathematics education students of FKIP Unram on the online learning process, abilities after online learning, and to describe related to online learning in the covid-19 era in mathematics education students of FKIP Unram in the 2020/2021 academic year. This research was carried out using descriptive qualitative research methods, for data collection a questionnaire was distributed via google form, with a sample of mathematics education students who were active and learning online in the 2020/2021 academic year. The instrument used in this study is a closed questionnaire, where respondents just choose the answers that are already available. The results showed that the perception of students of the Mathematics Education Study Program FKIP Unram towards the online learning process in the 2020/2021 academic year was categorized as good with a percentage of $79.13 \%$. Meanwhile, students' perceptions of abilities after online learning are in good category with a percentage of $70.44 \%$. Based on the results of the percentage scores for each indicator of the perception of the online learning process and ability after online learning, there are several things that must be maintained and developed in online learning at the Unram Mathematics Education Study Program including, the availability of learning materials or materials in the form of modules or textbooks, lecture contracts/RPS, the application of the google meet application, assessment and feedback that can increase student activity.
\end{abstract}

Keywords: perception; online learning

\begin{abstract}
Abstrak
Penelitian ini bertujuan untuk mengetahui persepsi mahasiswa pendidikan matematika FKIP Unram terhadap proses pembelajaran daring, kemampuan setelah pembelajaran daring, dan untuk mendeskripsikan terkait dengan pembelajaran daring di era covid-19 pada mahasiswa pendidikan matematika FKIP Unram tahun akademik 2020/2021. Penelitian ini dilakukan dengan metode penelitian kualitatif deskriptif, untuk pengambilan data dilakukan penyebaran angket melalui google form, dengan sampel mahasiswa pendidikan matematika yang aktif dan belajar secara daring pada tahun akademik 2020/2021. Instrumen yang digunakan dalam penelitian ini adalah sebuah angket tertutup, dimana responden tinggal memilih jawaban yang sudah tersedia. Hasil penelitian menunjukkan bahwa persepsi mahasiswa Program Studi Pendidikan Matematika FKIP Unram terhadap proses pembelajaran daring pada tahun akademik 2020/2021 berkategori baik dengan persentase sebesar 79,13\%. Sedangkan persepsi mahasiswa terhadap kemampuan setelah pembelajaran daring berkategori baik dengan persentase sebesar 70,44\%. Berdasarkan hasil persentase skor untuk setiap indikator persepsi proses pembelajaran daring dan kemampuan setelah pembelajaran daring, ada beberapa hal yang harus dipertahankan dan dikembangkan dalam pembelajaran daring di Prodi Pendidikan Matematika Unram diantaranya, ketersediaan materi atau bahan pelajaran berupa modul atau buku paket, kontrak perkuliahan/RPS, penerapan aplikasi google meet, penilaian dan umpan balik yang dapat meningkatkan keaktifan mahasiswa.
\end{abstract}

Kata Kunci: persepsi; pembelajaran daring 


\section{PENDAHULUAN}

Pendidikan adalah upaya manusia untuk memanusiakan manusia. Manusia pada hakikatnya adalah makhluk tuhan yang paling tinggi dibandingkan dengan makhluk lain ciptaanNya disebabkan memiliki kemampuan berbahasa dan akal pikiran/rasio, sehingga manusia mampu mengembangkan dirinya sebagai manusia yang berbudaya (Turmuzi dan Hayati, L., 2012).

Pendidikan bagi kehidupan umat manusia merupakan kebutuhan mutlak yang harus dipenuhi sepanjang hayat. Setiap manusia membutuhkan pendidikan, sampai kapanpun dan dimanapun ia berada. Pendidikan ditujukan untuk mengembangkan kecerdasan intelektual dan kecemerlangan akademik manusia melalui pendidikan disiplin ilmu. Pendidikan adalah segala pengalaman belajar yang berlangsung dalam segala lingkungan (Rulam, A., 2014). Melalui pendidikan, manusia menjadi lebih berkualitas dan berbudi pekerti luhur. Untuk menjadi seseorang yang berpendidikan maka harus ditempuh dengan cara belajar.

Belajar merupakan aktivitas interaksi aktif individu terhadap lingkungan sehingga terjadi perubahan tingkah laku (Ridwan, 2015). Winkel (dalam Turmuzi, 2012) menyatakan bahwa belajar merupakan suatu proses (aktivitas) mental atau psikis yang berlangsung dalam interaksi aktif antara seseorang (organisme) dengan lingkungannya yang menghasilkan perubahan-perubahan tingkah laku, baik pengetahuan, pemahaman, keterampilan, nilai atau sikap. Sedangkan menurut Slameto (dalam Turmuzi, 2012) belajar juga sebagai hasil pengalamannya sendiri. Suryosubroto (dalam Turmuzi, 2012) menyatakan bahwa belajar bukan hanya penguasaan hasil latihan, bukan hanya suatu hasil atau tujuan, bukan hanya mengingat melainkan memahami. Proses belajar akan dapat berjalan dengan baik jika siswa atau mahasiswa menyukai pelajaran, lingkungan, cara penyampaian materi dan persepsi terhadap pembelajaran yang berlangsung.

Proses pembelajaran di Program Studi Pendidikan Matematika Universitas Mataram pada kondisi sekarang ini berbeda dengan biasanya. Karena adanya wabah virus corona (COVID-19) akibatnya proses pembelajaran dilakukan secara daring. Pembelajaran daring ini dilakukan untuk mengantisipasi penyebaran virus tersebut. Berdasarkan hasil observasi peneliti diperoleh bahwa beberapa mahasiswa Program Studi Pendidikan Matematika memiliki persepsi yang berbeda-beda terhadap pembelajaran daring. Ada yang merasa dipermudah dengan adanya pembelajaran daring, namun ada pula yang merasa kesulitan dengan pembelajaran daring.

Pareek, U. (1996) mengemukakan bahwa persepsi adalah proses menerima atau menyeleksi, mengorganisasikan, mengartikan, menguji dan memberi reaksi kepada rangsangan panca indera atau data. Sedangkan menurut Machfoeds, Mahmud. (2011) mengemukakan bahwa persepsi adalah proses pemilihan, penyusunan, dan penafsiran informasi untuk mendapatkan arti. Menurut Tan (2011) persepsi adalah suatu proses tentang petunjuk-petunjuk inderawi (sensory) dan pengalaman masa lampau yang 
relevan diorganisasikan untuk memberikan kepada kita gambaran yang terstruktur dan bermakna pada suatu situasi tertentu.

Pembelajaran daring adalah proses belajar mengajar yang memanfaatkan internet dan media digital dalam penyampaian materinya. Pembelajaran daring atau online learning meliputi aspek perangkat keras (infrastruktur) berupa seperangkat computer yang saling berhubungan satu sama lain dan memiliki kemampuan untuk mengirimkan data, baik berupa teks, pesan, grafis maupun suara. Menurut Harususilo, Y. E., (2020) ada lima tahapan dalam pelaksanaan pembelajaran daring yaitu:

1. Pendidik menyediakan bahan pelajaran.

2. Proses pembelajaran daring menggunakan berbagai alternative media online/daring, seperti whatsapp grup, google class room, google meet dan lain-lain.

3. Peserta didik mempelajari materi dan mengerjakan tugas yang diberikan oleh pendidik.

4. Pendidik melakukan monitoring pelaksanaan proses pembelajaran daring.

5. Pendidik memberikan penjelasan jika ada pertanyaan peserta didik dan juga membuat umpan balik atas pembelajaran daring yang telah dilakukan.

Setelah melaksanakan proses pembelajaran diharapkan peserta didik mempuanyai kemampuan, berikut kemampuan setelah belajar menurut Gagne, Robert, M. (1977) meliputi:

1. Kemampuan intelektual, yaitu menerapkan konsep dan peraturan untuk mengatasi masalah dan ide-ide untuk menghasilkan produk.

2. Strategi Kognitif, yaitu keterampilan peserta didik untuk mengatur proses internal perhatian, belajar, ingatan dan pikiran.

3. Informasi verbal, yaitu menyebut, menceritakan atau menggambarkan informasi yang telah tersimpan sebelumnya.

4. Kemampuan keterampilan motorik (skill), yaitu melaksanakan suatu tindakan dengan tepat dan cepat.

5. Sikap, menentukan tindakan pribadi.

Berdasarkan uraian di atas dan hasil observasi, peneliti tertarik untuk meneliti terkait persepsi mahasiswa Program Studi Pendidikan Matematika Universitas Mataram terhadap pembelajaran daring di era COVID-19.

\section{METODE PELAKSANAAN}

Jenis penelitian ini adalah penelitian kualitatif deskriptif. Menurut Bogdan dan Taylor sebagaimana yang dikutip oleh Moleong, L.J. (2016), penelitian kualitatif adalah prosedur penelitian yang menghasilkan data deskriptif berupa kata-kata tertulis atau lisan dari orang-orang dan perilaku yang diamati. Sementara itu, penelitian deskriptif adalah suatu bentuk penelitian yang ditujukan untuk mendeskripsikan atau menggambarkan fenomena-fenomena yang ada, baik fenomena alamiah maupun rekayasa manusia (Moleong, L.J., 2000). Penelitian ini bertujuan untuk mengetahui 
persepsi mahasiswa pendidikan matematika FKIP Universitas Mataram terhadap proses pembelajaran daring dan kemampuan setelah pembelajaran online di era COVID-19.

Instrumen yang digunakan dalam penelitian ini berupa angket yang dibuat menggunakan google form. Menurut Prayitno, S. (2018) angket atau kuesioner adalah Teknik penilaian non tes tertulis untuk menggali informasi tentang pendapat, aspirasi, keyakinan dan lain-lain. Angket yang digunakan adalah angket tertutup, dimana responden tinggal memilih jawaban yang sudah tersedia yang akan dikirim melalui google form.

Validitas yang digunakan dalam penelitian ini adalah validitas isi dengan teknik indeks validitas Aiken's V. . Formula yang diajukan oleh Aiken adalah sebagai berikut (Azwar, S., 2012).

$$
V=\frac{\sum s}{n(C-1)}
$$

Keterangan:

$\mathrm{S}=\mathrm{r}-\mathrm{Lo}$

$\mathrm{Lo}=$ angka penilaian terendah

$\mathrm{C}=$ angka penilaian tertinggi

$\mathrm{R}=$ angka yang diberikan oleh penilai

$\mathrm{n}=$ jumlah validator

Adapun yang bertindak sebagai penilai atau validator dalam penelitian ini yaitu 3 Dosen Program Studi Pendidikan Matematika FKIP Universitas Mataram, dan 2 guru mata pelajaran matematika. Tingkat kevalidan instrumen pada hasil perhitungan validitas Aiken dapat dilihat pada tabel tingkat kevalidan menurut Arikunto, S. (2018) berikut ini.

Tabel 1. Tingkat Kevalidan

\begin{tabular}{cc}
\hline Rentang Persentase & Kategori \\
\hline $0,80 \leq \mathrm{V} \leq 1,00$ & Sangat Valid \\
$0,60 \leq \mathrm{V}<0,80$ & Valid \\
$0,40 \leq \mathrm{V}<0,60$ & Cukup Valid \\
$0,20 \leq \mathrm{V}<0,40$ & Kurang Valid \\
$0,00 \leq \mathrm{V}<0,20$ & Tidak Valid \\
\hline
\end{tabular}

Data tentang persepsi mahasiswa Prodi Pendidikan Matematika FKIP Unram terhadap proses pembelajaran daring dan kemampuan setelah pembelajaran daring di era covid19 dianalisis menggunakan skala Likert dengan rumus sebagai berikut:

$$
p=\frac{\text { Total skor }}{\text { SMI }} \times 100 \%
$$

Keterangan: $p=$ indeks persentase; Total skor $=$ jumlah dari skor yang diperoleh setiap responden; SMI = Skor maksimum ideal responden dimana: $\mathrm{SMI}=$ jumlah responden x skala tertinggi likert. 
Kemudian untuk pedoman pengkategoriannya adalah sebagai berikut:

Tabel 2. Pedoman Kategori

\begin{tabular}{cc}
\hline Rentang Persentase & Kategori \\
\hline $80 \%-100 \%$ & Sangat Baik \\
$60 \%-79,99 \%$ & Baik \\
$40 \%-59,99 \%$ & Cukup \\
$20 \%-39,99 \%$ & Kurang \\
$0 \%-19,99 \%$ & Sangat Kurang \\
\hline
\end{tabular}

\section{HASIL DAN PEMBAHASAN}

\subsection{Validitas Instrumen}

Terdapat lima aspek yang dinilai dalam intrumen penelitian ini. Aspek pertama yaitu butir pernyataan mengukur persepsi proses pembelajaran daring. Aspek kedua yaitu butir pernyataan menggunakan kaidah Bahasa Indonesia dengan EYD (Ejaan Yang Disempurnakan). Aspek ketiga yaitu butir pernyataan menggunakan kalimat yang jelas sehingga tidak menimbulkan penafsiran ganda. Aspek keempat butir pernyataan menggunakan bahasa yang mudah dipahami. Aspek kelima yaitu butir pernyataan sudah sesuai dengan indikator.

Berdasarkan perhitungan dengan menggunakan rumus Aiken's V, diperoleh rata-rata validitas isi instrumen dari kelima aspek penilaian seperti pada Tabel 3 berikut ini.

Tabel 3. Rata-rata Validitas Isi Instrumen

\begin{tabular}{ccc}
\hline Aspek & Rata-rata & Kategori \\
\hline 1 & 0,81 & Sangat Valid \\
2 & 0,80 & Sangat Valid \\
3 & 0,82 & Sangat Valid \\
4 & 0,80 & Sangat Valid \\
5 & 0,80 & Sangat Valid \\
\hline
\end{tabular}

Tabel 3 di atas menunjukkan bahwa rata-rata validitas instrumen pada aspek pertama sebesar 0,81, pada aspek kedua sebesar 0,80, pada aspek ketiga sebesar 0,82, pada aspek keempat sebesar 0,80, dan aspek kelima sebesar 0,80. Sehingga dapat disimpulkan bahwa kelima aspek tersebut berkategori sangat valid dan telah memenuhi kriteria untuk dijadikan alat pengambil data dalam penelitian.

\subsection{Persepsi Mahasiswa Terhadap Pembelajaran Daring}

Berikut akan disajikan Tabel 4 dari indikator persepsi terhadap proses dan kemampuan setelah pembelajaran daring. Indikator persepsi terhadap proses pembelajaran daring didapatkan dari pemaparan Harisusilo tentang tahapan dalam pelaksanaan 
pembelajaran daring. Sedangkan indikator persepsi setelah pembelajaran daring berpedoman pada Robert M. Gagne tentang kemampuan setelah belajar.

Tabel 4. Indikator Persepsi Terhadap Proses dan Kemampuan Setelah Pembelajaran Daring

\begin{tabular}{|c|c|}
\hline Persepsi & Indikator \\
\hline \multirow{5}{*}{$\begin{array}{l}\text { Terhadap Proses } \\
\text { Pembelajaran Daring }\end{array}$} & Pendidik menyediakan bahan pelajaran \\
\hline & $\begin{array}{l}\text { Proses pembelajaran daring dilakukan menggunakan } \\
\text { berbagai alternatif media daring }\end{array}$ \\
\hline & $\begin{array}{l}\text { Peserta didik mempelajari materi dan mengerjakan tugas } \\
\text { yang diberikan oleh pendidik }\end{array}$ \\
\hline & $\begin{array}{l}\begin{array}{l}\text { Pendidik melakukan monitoring } \\
\text { pembelajaran daring }\end{array} \\
\end{array}$ \\
\hline & $\begin{array}{l}\text { Pendidik memberikan penjelasan jika ada pertanyaan peserta } \\
\text { didik dan juga membuat umpan balik atas pembelajaran } \\
\text { daring yang telah dilakukan }\end{array}$ \\
\hline \multirow{5}{*}{$\begin{array}{l}\text { Terhadap Kemampuan } \\
\text { Setelah Pembelajaran } \\
\text { Daring }\end{array}$} & Kemampuan Intelektual \\
\hline & Strategi Kognitif \\
\hline & Informasi Verbal \\
\hline & Kemampuan Keterampilan Motorik (Skill) \\
\hline & Sikap \\
\hline
\end{tabular}

Berdasarkan analisis data yang telah dilakukan maka didapatkan hasil sebagai berikut.

Tabel 5. Kategori Persepsi Mahasiswa Berdasarkan Total Skor dan Persentase Total Skor

\begin{tabular}{|c|c|c|c|}
\hline No. Butir & Total Skor & Persetase (\%) & Kategori \\
\hline \multicolumn{4}{|c|}{ Aspek persepsi mahasiswa terhadap proses pembelajaran daring } \\
\hline \multicolumn{4}{|c|}{ Indikator 1} \\
\hline 1 & 369 & 91.11 & Sangat Baik \\
\hline 2 & 331 & 81.73 & Sangat Baik \\
\hline 3 & 304 & 75.06 & Baik \\
\hline 4 & 314 & 77.53 & Baik \\
\hline 5 & 343 & 84.69 & Sangat Baik \\
\hline \multicolumn{4}{|c|}{ Indikator 2} \\
\hline 6 & 201 & 49.63 & Cukup \\
\hline 7 & 206 & 50.86 & Cukup \\
\hline 8 & 194 & 47.90 & Cukup \\
\hline 9 & 196 & 48.40 & Cukup \\
\hline 10 & 367 & 90.62 & Sangat Baik \\
\hline 11 & 362 & 89.38 & Sangat Baik \\
\hline \multicolumn{4}{|c|}{ Indikator 3} \\
\hline 12 & 323 & 79.75 & Baik \\
\hline 13 & 364 & 89.88 & Sangat Baik \\
\hline 14 & 340 & 83.95 & Baik \\
\hline \multicolumn{4}{|c|}{ Indikator 4} \\
\hline 15 & 373 & 92.10 & Sangat Baik \\
\hline 16 & 368 & 90.86 & Sangat Baik \\
\hline \multicolumn{4}{|c|}{ Indikator 5} \\
\hline 17 & 334 & 82.47 & Sangat Baik \\
\hline 18 & 363 & 89.63 & Sangat Baik \\
\hline 19 & 198 & 48.89 & Cukup \\
\hline 20 & 278 & 68.64 & Baik \\
\hline 21 & 342 & 84.44 & Sangat Baik \\
\hline
\end{tabular}




\begin{tabular}{|c|c|c|c|}
\hline \multicolumn{4}{|c|}{$\begin{array}{l}\text { Aspek persepsi mahasiswa terhadap kemampuan belajar setelah pembelajaran } \\
\text { daring }\end{array}$} \\
\hline \multicolumn{4}{|c|}{ Indikator 1} \\
\hline 22 & 304 & 75.06 & Baik \\
\hline 23 & 259 & 63.95 & Baik \\
\hline \multicolumn{4}{|c|}{ Indikator 2} \\
\hline 24 & 269 & 66.42 & Baik \\
\hline 25 & 307 & 75.80 & Baik \\
\hline \multicolumn{4}{|c|}{ Indkator 3} \\
\hline 26 & 302 & 74.57 & Baik \\
\hline 27 & 289 & 71.36 & Baik \\
\hline \multicolumn{4}{|c|}{ Indkator 4} \\
\hline 28 & 283 & 69.88 & Baik \\
\hline 29 & 271 & 66.91 & Baik \\
\hline \multicolumn{4}{|c|}{ Indikator 5} \\
\hline 30 & 353 & 87.16 & Baik \\
\hline 31 & 319 & 78.77 & Baik \\
\hline 32 & 181 & 44.69 & Cukup \\
\hline
\end{tabular}

Data yang diperoleh dari penelitian ini adalah data dari hasil penyebaran angket melalui google form. Jumlah mahasiswa yang menjadi sampel dalam penelitian ini adalah 85 mahasiswa yang tersebar dari mahasiswa semester III, V dan VII. Berikut adalah data setelah diolah untuk mencari persentase persepsi mahasiswa Prodi Pendidikan Matematika FKIP Unram terhadap pembelajaran daring di era COVID-19.

Hasil menunjukkan bahwa terdapat tiga kategori persepsi mahasiswa terhadap proses pembelajaran daring yaitu kategori sangat baik, baik dan cukup, dimana persentase tertinggi terdapat pada butir pernyataan nomor 15 yaitu sebesar $92.10 \%$, dan persentase terendah terdapat pada butir pernyataan nomor 8 yaitu sebesar $47.90 \%$. Sedangkan pada aspek persepsi terhadap kemampuan belajar setelah pembelajaran daring juga terdiri atas tiga kategori yaitu kategori sangat baik, baik, dan cukup, dimana persentase tertinggi terdapat pada butir pernyataan nomor 30 yaitu sebesar $87.16 \%$, dan persentase terendah terapat pada butir pernyataan nomor 32 yaitu sebesar $44.69 \%$.

\subsection{Pembahasan}

1. Persepsi Mahasiswa Terhadap Proses Pembelajran Daring dan Kemampuan Setelah Pembelajaran Daring

Persepsi mahasiswa terhadap proses mahasiswa pembelajaran daring dan kemampuan setelah pembelajaran daring dapat dilihat pada gambar grafik berikut ini. 


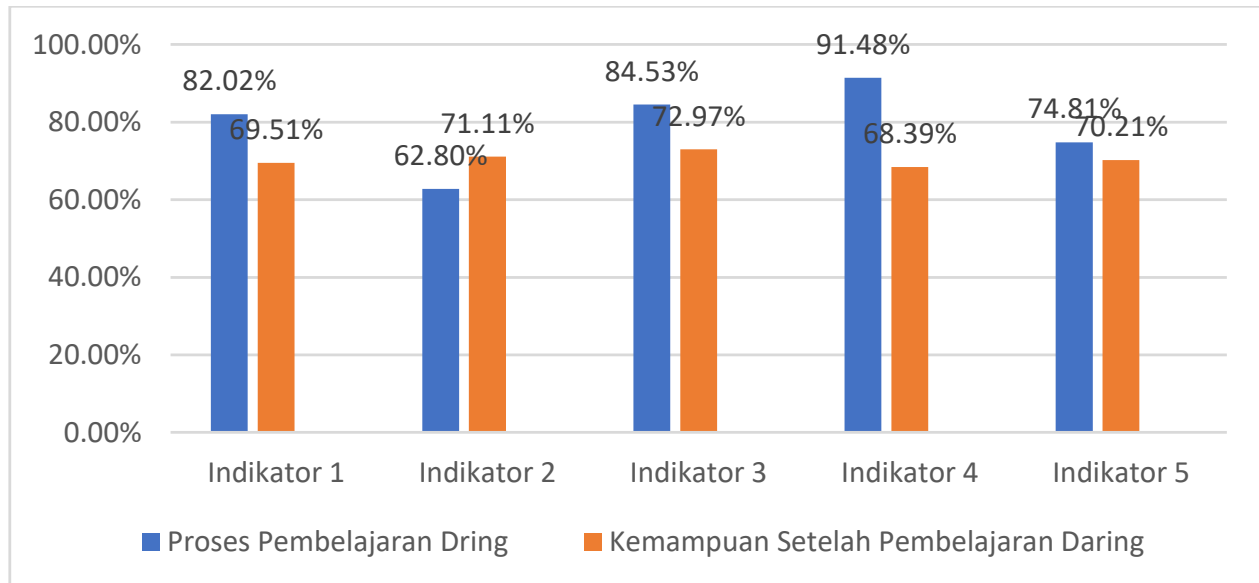

Gambar 1. Persepsi Mahasiswa Terhadap Proses dan Kemampuan Setelah Pembelajaran Daring

Apabila dirata-ratakan semua indikatornya maka dapat disimpulkan bahwa persepsi mahasiswa Program Studi Pendidikan Matematika Unram terhadap proses pembelajaran daring pada tahun ajaran 2020/2021 berkategori baik dengan persentase sebesar 79,13\%, dan kemampuan setelah pembelajaran daring berkategori baik dengan persentase sebesar 70,44\%. Hasil penelitian ini sejalan dengan hasil penelitian yang dilakukan Maulana, H. A., \& Hamidi, M. (2020) tentang persepsi mahasiswa terhadap pembelajaran daring yang mengatakan bahwa persepsi mahasiswa terhadap pembelajaran daring bersifat positif, dengan rincian aspek belajar mengajar sebesar $66,4 \%$, aspek kapabilitas (kemampuan dosen) sebesar 74,6\%, dan aspek sarana dan prasarana sebesar $72,6 \%$. Hal ini berarti bahwa pembelajaran daring sudah berjalan dengan baik. Namun bertolak belakang dengan hasil penelitian yang didapatkan oleh Hadi, L. (2020) yang mengatakan bahwa pembelajaran daring menyulitkan bagi mahasiswa karena kurangnya bahan belajar dan kurangnya akses internet, sehingga mahasiswa lebih menyukai pembelajaran luring daripada daring.

\section{Pembelajaran Daring Prodi Pendidikan Matematika FKIP Unram}

Dari hasil penelitian dapat disimpulkan bahwa pembelajaran daring di program studi Pendidikan Matematika Universitas Mataram sudah baik. Namun juga perlu ditingkatkan agar tujuan pembelajaran sesuai dengan yang diharapkan. Terdapat beberapa poin yang perlu dipertahankan dalam pembelajaran daring di Prodi Pendidikan Matematika FKIP Unram berdasarkan skor tertinggi dari data hasil penelitian yaitu:

1. Dosen selalu menyediakan materi atau bahan pelajaran.

2. Materi yang diberikan oleh dosen berupa modul atau buku paket.

3. Materi yang disajikan secara daring sesuai dengan kontrak perkuliahan/RPS.

4. Proses pembelajaran daring dilakukan menggunakan aplikasi google meet.

5. Mahasiswa lebih mudah menggunakan aplikasi google meet pada proses pembelajaran daring.

6. Mahasiswa selalu mengerjakan tugas yang diberikan oleh dosen.

7. Dosen selalu mengecek kehadiran mahasiswa. 
8. Dosen memberikan nilai tambahan kepada mahasiswa yang aktif bertanya dan menjawab pada proses pembelajaran daring.

9. Dosen selalu memberikan kesempatan kepada mahasiswa untuk bertanya dan berdiskusi.

10. Dosen memberikan respon terhadap pertanyaan yang muncul selama proses perkuliahan daring.

11. Dosen memberikan umpan balik dengan cara mengajukan pertanyaan kepada mahasiswa terkait materi yang telah dipelajari.

Dari nomor 1,2, dan 3 di atas dapat diketahui bahwa Dosen Prodi Pendidikan Matematika FKIP Unram selalu menyediakan materi atau bahan pelajaran pada proses pembelajaran daring, sehingga mahasiswa tidak kekurangan materi pembelajaran. Materi yang diberikan oleh Dosen berupa modul atau buku paket sehingga memungkinkan mahasiswa lebih mudah dalam memahami materi. Dari nomor 4 dan 5 dapat diketahui bahwa proses pembelajaran daring menggunakan aplikasi google meet dalam proses pembelajaran. Mahasiswa merasa lebih mudah menggunakan aplikasi google meet daripada aplikasi daring lainnya seperti google classroom dan yang lainnya. Namun dalam beberapa kesempatan juga proses pembelajaran daring menggunakan aplikasi whatsapp. Hal ini sedikit berbeda dengan hasil penelitian yang dilakukan oleh Zhafira, Ertika, \& Chairiyaton (2020) yang mengatakan bahwa media pembelajaran daring yang paling digemari ialah whatsapp dan google classroom.

Pada nomor 6 di atas dapat diketahui bahwa mahasiswa selalu mengerjakan tugas yang diberikan oleh dosen. Pada nomor 7 diketahui bahwa pada proses pembelajaran daring dosen selalu mengecek kehadiran mahasiswa, sehingga dosen mengetahui kehadiran mahasiswa pada proses pembelajaran. Dari hasil penelitian juga diketahui mahasiswa selalu hadir pada proses pembelajaran daring dan tidak pernah bolos. Menurut hasil penelitian Yudiawan, A. (2019) yang mengatakan bahwa semakin besar kehadiran peserta didik (absensi), semakin tinggi hasil dan kemampuan setelah belajar, dan sebaliknya. Hal ini dapat dilihat dari hasil penelitan yang menunjukkan bahwa kemampuan setelah belajar mahasiswa berkategori baik.

Selain memberikan nilai tambahan bagi mahasiswa yang aktif seperti pada nomor 8 , pada nomor 9 diketahui dosen juga selalu memberikan kesempatan kepada mahasiswa untuk bertanya dan berdiskusi, sehingga proses pembelajaran tidak monoton atau satu arah melainkan dua arah. Hal ini tentunya baik untuk mahasiswa maupun dosen agar proses pembelajara tidak kaku walaupun dilakukan secara daring. Menurut penelitian yang dilakukan oleh Dewi, P. S.I.Y., Kurniati, N., \& Wahidaturrahmi (2021) yang mengatakan bahwa adanya pengaruh yang signifikan antara kemampuan komunikasi dengan hasil belajar peserta didik. Dari hasil penelitian diketahui bahwa pada indikator kemampuan komunikasi mahasiswa sudah baik, maka diharapkan hasil belajar mahasiswa juga baik.

Pada nomor 10 dan 11, dosen memberikan respon terhadap pertanyaan yang muncul selama proses perkuliahan daring, sehingga apabila mahasiswa tidak mengerti atas 
materi yang diajarkan oleh dosen, bisa ditanyakan kepada dosen yang bersangkutan. Selain itu dosen juga memberikan umpan balik dengan cara mengajukan pertanyaan kepada mahasiswa terkait materi yang telah dipelajari, sehingga dosen bisa mengetahui sejauh mana pemahaman mahasiswa dari materi pembelajaran yang telah diajarkan. Maka dapat diketahui kinerja dosen pada proses pembelajaran daring sudah baik. Hal ini sesuai dengan hasil penelitian Kurniati, N., Baidowi, Hikmah, N. (2018) tentang kinerja dosen sebelum diberlakukan pembelajaran daring yaitu persepsi mahasiswa tentang kinerja dosen prodi pendidikan matematika FKIP Unram tahun akademik 2015/2016 berkategori baik dengan persentase skor 69,5\%. Artinya lebih dari 50\% dan kurang dari atau sama dengan $75 \%$ dari jumlah yang aktif di prodi pendidikan matematika FKIP Unram sudah melaksanakan proses perkuliahan dengan baik. Hal ini berarti bahwa proses perkuliahan di prodi pendidikan matematika FKIP Unram sebelum maupun sesudah pembelajaran daring sudah berjalan dengan baik.

Dari hasil penelitian dan uraian di atas dapat disimpulkan bahwa proses pembelajaran daring di Prodi Pendidikan Matematika FKIP Universitas Mataram sudah baik dan sesuai dengan prosedur, yaitu seperti dosen mengecek kehadiran mahasiswa, menyiapkan materi pembelajaran, mahasiswa selalu mengerjakan dan mengumpulkan tugas, serta terjalinnya proses pembelajaran yang interaktif antara dosen dengan mahasiswa ataupun mahasiswa dengan mahasiswa. Hal ini sejalan dengan penelitian yang dilakukan oleh Saragih, O., Sebayang, F. A. A., Sinaga, A. B., \& Ridlo, M. R. (2020) yang mengatakan bahwa berdasarkan analisis data deskriptif, ditemukan bahwa mayoritas mahasiswa memiliki persepsi positif terkait pelaksanaan perkuliahan daring dalam dua aspek yaitu aspek proses belajar mengajar dan aspek kapabilitas dosen, namun memiliki persepsi negatif dalam aspek sarana dan prasarana. Keterbatasan jaringan internet dan perangkat belajar yang dimiliki oleh mahasiswa menjadi kendala bagi mahasiswa dalam mengikuti perkuliahan daring.

\section{SIMPULAN}

Berdasarkan hasil penelitian tentang persepsi mahasiswa Program Studi Pendidikan Matematika Universitas Mataram didapatkan beberapa kesimpulan sebagai berikut:

a. Persepsi mahasiswa Program Studi Pendidikan Matematika FKIP Unram terhadap proses pembelajaran daring pada tahun 2020/2021 berkategori baik dengan persentase sebesar 79,13\%.

b. Persepsi mahasiswa Program Studi Pendidikan Matematika FKIP Unram terhadap kemampuan setelah pembelajaran daring pada tahun 2020/2021 berkategori baik dengan persentase sebesar $70,44 \%$.

c. Dari hasil penelitian dan pembahasan dapat disimpulkan bahwa proses pembelajaran daring di Prodi Pendidikan Matematika FKIP Universitas Mataram sudah baik dan sesuai dengan prosedur, yaitu seperti dosen mengecek kehadiran mahasiswa, menyiapkan materi pembelajaran, mahasiswa selalu mengerjakan dan mengumpulkan tugas, serta terjalinnya proses pembelajaran yang interaktif antara dosen dengan mahasiswa ataupun mahasiswa dengan mahasiswa. 


\section{REFERENSI}

Arikunto, S. (2018). Dasar-dasar Evaluasi Pendidikan Edisi 3. Jakarta: Bumi Aksara.

Azwar, S. (2012). Reliabilitas dan Validitas. Edisi 4. Yogyakarta: Pustaka Belajar.

Dewi, P. S.I.Y., Kurniati, N., \& Wahidaturrahmi. (2021). Pengaruh Kepercayaan Diri dan Kemampuan Komunikasi Matematika Terhadap Hasil Belajar Matematika Siswa, Griya Jurnal of Mathematics Education and Application, 1(2), 122-131.

Gagne, Robert, M. (1977). The Conditions of Learning (3rd). New York: Holt, Rinehart and Winston.

Hadi, L. (2020). Persepsi Mahasiswa Terhadap Pembelajaran Daring di Masa Pandemik Covid-19, Jurnal Zarah, 8 (2), 56-61.

Harususilo, Y. E. (2020). Panduan 5 Tahap Proses Belajar di Rumah untuk Sekolah dan Orangtua. https://www.kompas.com/edu/read/2020/03/17/121116571/panduan-5-tahap-prosesbelajar-di-rumah-untuk-sekolah-dan-orangtua?page=all. Diakses tanggal 5 November 2020.

Kurniati, N., Baidowi, Hikmah, N. (2018). Persepsi Mahasiswa Pendidikan Matematika Terhadap Kinerja Dosen Dalam Proses Perkuliahan, Jurnal Pijar MIPA, 13(1), 32-36.

Machfoeds, Mahmud. (2011). Pengantar Pemasaran Modern. Penerbit:UPP AMP YKPN.

Maulana, H. A., \& Hamidi, M. (2020). Persepsi Mahasiswa Terhadap Pembelajaran Daring pada Mata Kuliah Praktik di Pendidikan Vokasi, Jurnal Pendidikan, 8(2), 224-231.

Moleong, L.J. (2016). Metodologi Penelitian Kualitatif Edisi Revisi. Bandung: PT. Remaja Rosdakarya.

Moleong, L.J. (2000). Metodologi Penelitian Kualitatif. Bandung: PT. Remaja Rosdakarya.

Pareek, U. (1996). Perilaku Organisasi. Cet. 3. Jakarta: PT. Ikrar Mandiri.

Prayitno, S. (2018). Evaluasi Pembelajaran Matematika. Mataram: Duta Pustaka Ilmu.

Ridwan, (2015). Inovasi Pembelajaran. Jakarta: Bumi Aksara.

Rulam, A. (2014). Pengantar Pendidikan. Yogyakarta: Ar-ruzz Media, h. 36-37.

Saragih, O., Sebayang, F. A. A., Sinaga, A. B., \& Ridlo, M. R. (2020). Persepsi Mahasiswa Terhadap Pembelajaran Daring Selama Pandemi Covid-19. Jurnal Penelitian Pendidikan \& Pembelajaran, 7(3), 178-191.

Tan. (2011). Sukses Mengelola Marketing Mix, CRM, Custumer Value dan Custumer Dependency. Cetakan pertama. Penerbit: Alfabeta, Bandung.

Turmuzi, (2012). Strategi Pembelajaran Matematika. Mataram: Arga Puji Press.

Turmuzi dan Hayati, L. (2012). Telaah Kurikulum Matematika. Mataram: Arga Puji Press.

Yudiawan, A. (2019). Analisis Korelasi Tingkat Absensi dengan Hasil Belajar Siswa MTs. Sains al-Gebra Kota Sorong Papua Barat, Jurnal Kependidikan, 11(2), 353-373.

Zhafira, N. H., Ertika, Y., \& Chairiyaton. (2020). Persepsi Mahasiswa Terhadap Perkuliahan Daring Sebagai Sarana Pembelajaran, Jurnal Bisnis Dan Kajian Strategi Manajemen, 4(1), $167-174$ 